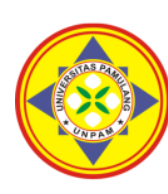

\title{
PENGARUH DISIPLIN KERJA DAN MOTIVASI TERHADAP KINERJA KARYAWAN PADA KUD SOLIAMITRA LIMO - DEPOK
}

\author{
${ }^{1 *}$ Rini Dianti Fauzi, ${ }^{2}$ Syifa Fauziyah \\ Universitas Pamulang, Tangerang Selatan, Banten, Indonesia \\ *dosen01425@unpam.ac.id
}

\begin{abstract}
Abstrak
Penelitian ini bertujuan untuk menguji secara parsial pengaruh displin kerja terhadap kinerja karyawan pada KUD Soliamitra, Limo-Depok, menguji secara parsial untuk mengetahui pengaruh Motivasi terhadap kinerja karyawan pada KUD Soliamitra, limo-Depok,dan menguji secara simultan untuk mengetahui pengaruh disisplin kerja dan Motivasi terhadap kinerja karyawan pada KUD Soliamitra, Limo-Depok. Metode penelitian ini menggunakan metode kuantitatif dengan pendekatan asosiatif. Sampel yang digunakan adalah sampel jenuh yakni seluruh karyawan KUD Soliamitra LimoDepok.yang berjumlah 80 karyawan. dari hasil uji hipotesis secara parsial (uji t) menunjukan bahwa disiplin kerja mempunyai pengaruh terhadap kinerja karyawan dengan nilai thitung $>$ ttabel $(4,269>$ 1,99125). Sedangkan hasil uji hipotesis secara parsial (uji t) menunjukan bahwa variabel motivasi mempunyai pengaruh terhadap kinerja karyawan dengan nilai thitung $>$ ttabel $(2,271>1,99125)$. Hasil uji hipotesis secara simultan (uji f) menunjukan bahwa disiplin kerja dan motivasi mempunyai pengaruh terhadap kinerja karyawan dengan nilai fhitung $>$ ftabel $(11,959>3,11)$ dengan nilai sig. sebesar 0,000b $<0,05$.
\end{abstract}

Kata Kunci: Disiplin Kerja, Motivasi, Kinerja Karyawan

\section{Abstract}

This study aims to partially test the effect of work discipline on employee performance in KUD Soliamitra, limo-Depok, partially testing to determine the effect of motivation on employee performance at KUD Soliamitra, Limo-Depok, and testing simultaneously to determine the effect of work discipline and motivation. on employee performance at KUD Soliamitra, Limo-Depok. This research method uses quantitative methods with an associative approach. The sample used is a saturated sample, namely all employees of KUD Soliamitra Limo-Depok, totaling 80 employees. From the results of the partial hypothesis test ( $t$ test), it shows that work discipline has an influence on employee performance with a value of tcount $>$ ttable $(4.269>1.99125)$. While the partial hypothesis test ( $t$ test) shows that the motivation variable has an influence on employee performance with tcount> ttable (2.271> 1.99125). Simultaneous hypothesis test results ( $f$ test) show that work discipline and motivation have an influence on employee performance with a value of fcount $>$ ftable (11.959> 3.11) with a sig. equal to $0.000 b<0.05$.

Keywords: Work Discipline, Motivation, Employee Performance

\section{PENDAHULUAN}

Setiap perusahaan baik itu di dalam suatu instansi yang melayani kepentingan publik seperti instansi pemerintah maupun organisasi swasta, menginginkan adanya pencapaian maksimal yang terkait dengan peningkatan hasil kerja demi tercapainya tujuan organisasi. untuk mencapai tujuan organisasi salah satu elemen yang penting yang harus diperhatikan yaitu sumber daya manusia. hal ini karena sumber daya manusia yang melaksanakan dan mengatur serta menjalankan kegiatan organisasi tersebut, dengan perkembangan ilmu pengetahuan dan teknologi yang semakin pesat, maka dituntut sumber daya manusia yang mumpuni dan berkualitas, sumber daya manusia saat ini memiliki peran yang sangat penting dalam berbagai sektor. Individu merupakan motor penggerak jalannya instansi dan tercapainya tujuan instansi, salah satunya sangat bergantung baik buruknya kinerja pegawai. untuk itu, instansi dalam hal ini pimpinan wajib memperhatikan kedisplinan pegawai dan mengarahkan 
serta memotivasi untuk meningkatkan kinerja pegawai.

Pegawai adalah aset terpenting dalam pencapaian tujuan suatu organisasi, di mana bila pegawai mampu menghasilkan kinerja yang baik dapat memberikan kontribusi yang besar dalam menjalankan aktivitas suatu organisasi.

Karyawan bukanlah mesin dan uang yang sifatnya pasif dan dapat dikuasai serta diatur sepenuhnya dalam mencapai tujuan perusahaan, melainkan aset berharga perusahaan yang harus dipelihara dengan baik. oleh karena itu, perusahaan dan karyawan harus mampu bekerjasama untuk mewujudkan kedisiplinan dalam melakukan setiap pekerjaan sehingga dapat meningkatkan kinerja karyawan tersebut menjadi lebih tinggi. kinerja merupakan hasil kerja yang di capai seseorang dalam melaksanakan tugas-tugas yang di bebankan kepadanya yang di dasarkan atas kecakapan, pengalaman dan kesungguhan serta waktu.keberadaan nya mampu menjalankan fungsi-fungsi manajemen dalam suatu organisasi secara efektif dan efesien. menurut Supriyatin (2013:15) "Manajemen sumber daya manusia merupakan tugas manajemen sumber daya manusia untuk mengelola manusia seefektif mungkin agar diperoleh suatu satuan sumber daya manusia yang merasa puas dan memuaskan".

Menurut Singodimedjo dalam Edy Sutrisno (2016:86) menyatakan bahwa "Disiplin adalah sikap kesediaan dan kerelaan seseorang untuk mematuhi dan menaati norma-norma peraturan yang berlaku disekitarnya". tanpa disiplin yang baik, sulit bagi organisasi maupun instansi mencapai hasil yang optimal. Disiplin merupakan kesadaran dan kesediaan seseorang mentaati semua peraturan instansi yang dibuat manajemen yang mengingat anggota instansi agar dapat dijalankan semua pegawai baik dengan kesadaran sendiri maupun dengan paksaan.

Tabel 1. Absensi Karyawan KUD Soliamitra- Depok Tahun 2016-2020

\begin{tabular}{|c|c|c|c|c|c|c|c|c|c|c|}
\hline \multirow[b]{2}{*}{ Thn } & \multicolumn{2}{|c|}{$\begin{array}{c}\text { Jenis } \\
\text { kelamin }\end{array}$} & \multirow{2}{*}{$\begin{array}{c}\text { Jumlah } \\
\text { Karyawan } \\
\text { (orang) } \\
\text { A }\end{array}$} & \multirow[b]{2}{*}{$\begin{array}{c}\text { Jhk } \\
\text { b }\end{array}$} & \multirow[b]{2}{*}{$\begin{array}{c}a \times b \\
c\end{array}$} & \multicolumn{4}{|c|}{ Kondisi Absensi } & \multirow[b]{2}{*}{$\begin{array}{c}\text { Persentase } \\
\% \\
\left(\mathrm{~g} / \mathrm{c}^{*} 100\right) \mathrm{h}\end{array}$} \\
\hline & $\mathbf{P}$ & L & & & & $\begin{array}{c}\text { Terlamat } \\
\text { D }\end{array}$ & $\begin{array}{c}\text { Alfa } \\
\text { e }\end{array}$ & $\begin{array}{c}\text { Bolos } \\
\mathrm{f}\end{array}$ & $\begin{array}{c}\text { Jumlah } \\
(d+e+f) \\
g\end{array}$ & \\
\hline 2016 & 19 & 24 & 80 & 288 & 23.040 & 67 & 41 & 32 & 140 & $48,6 \%$ \\
\hline 2017 & 24 & 32 & 80 & 288 & 23.040 & 33 & 51 & 32 & 116 & $40,28 \%$ \\
\hline 2018 & 35 & 37 & 80 & 288 & 23.040 & 51 & 62 & 17 & 130 & $45,14 \%$ \\
\hline 2019 & 42 & 38 & 80 & 288 & 23.040 & 69 & 51 & 35 & 15 & $45,14 \%$ \\
\hline 2020 & 42 & 38 & 80 & 288 & 23.040 & 54 & 43 & 33 & 139 & $48,26 \%$ \\
\hline
\end{tabular}

Sumber : Kud Soliamitra (2020)

Berdasarkan tabel di atas dapat di ketahui bahwa tingkat absensi karyawan KUD Soliamitra-Depok dalam periode 2016-2020 menunjukan trend yang fluktuatif, di mana pada tahun 2016 di mana jumlah karyawan yang terlambat,alfa dan bolos mencapai 140 atau 48,6\% dalam kurun waktu 288 hari kerja dengan kata lain dalam waktu 1 tahun. tahun 2017 mengalami penurunan sebesar 116 atau 40,28\%, tahun 2018 mengalami kenaikan sebesar 130 atau pada 45,14\% tahun 2019 mengalami kenaikan sebesar 155 atau $45,14 \%$ dan pada tahun 2020 mengalami penurunan mencapai 139 atau 48,26\% . jika melihat dari absensi karyawan tersebut jika tidak di lakukan evaluasi maka akan berakibat pada tingkat kedisiplinan karyawan menjadi rendah dan dapat menurunkan dan motivasi menurut para ahli .

Motivasi menjadi salah satu faktor penting yang perlu diperhatikan oleh perusahaan, apabila perusahaan menginginkan setiap karyawannya dapat memberikan kontribusi positif terhadap pencapaian tujuan perusahaan. karena dengan memotivasi, seorang karyawan akan memiliki semangat kerja yang tinggi di dalam melaksanakan pekerjaannya.sebaliknya tanpa adanya menghambat pencapain badan usaha tersebut.Berdasarkan pendapat mengenai 
motivasi, seorang karyawan tidak akan mempunyai semangat kerja, sehingga kinerja karyawan tersebut tidak berjalan secara maksimal dan tidak melakukan tugas nya dengan baik. karena sangat pentingnya motivasi kerja bagi seluruh karyawan, maka perusahan sangat perlu untuk terus menjaga agar motivasi karyawan tidak mengalami penurunan.perlu di ketahui bahwa setiap karyawan bekerja karena ingin memenuhi kebutuhan pribadi pada masing masing karyawan.

Dengan ini saya berikan hasil dari observasi pada karyawan KUD Soliamitra Depok sebagai berikut.

Tabel 2. Pemberian Motivasi (Materil dan Non Materil) untuk karyawan pada KUD Soliamitra Limo-Depok

\begin{tabular}{|l|l|c|}
\hline No & \multicolumn{1}{|c|}{$\begin{array}{c}\text { Pemberian Motivasi } \\
\text { (Materil dan Non Materil) }\end{array}$} & Keterangan \\
\hline \multicolumn{2}{|c|}{ (Kebutuhan fisiologis) } \\
\hline 1 & Upah Lembur (Kebutuhan Rasa Aman) & Ada \\
\hline 2. & Uang Makan Tambahan Tidak ada \\
\hline \multicolumn{2}{|c|}{ (Kebutuhan Penghargaan) } & Ada \\
\hline 3. & BPJS Ada \\
\hline 4. & Tunjanagan Hari Raya Ada \\
\hline 5. & Pensiun / Pesangon Ada \\
\hline \multicolumn{2}{|c|}{ (Kebutuhan Aktualisasi Diri) } \\
\hline 6. & Pengahargaan atas Loyalitas / Masa Kerja & Tidak Ada \\
\hline 7. & $\begin{array}{l}\text { Bonus Tahunan, Jika Seorang karyawan Mencapai } \\
\text { Target }\end{array}$ \\
\hline
\end{tabular}

Sumber : Kud Soliamitra- Depok

Berdasarkan tabel di atas dapat di simpulkan bahwa motivasi yang di berikan langsung dari pihak badan usaha kepada karyawan, adalah dengan memberikan upah lembur, namun badan usaha tersebut tidak memberikan uang makan tambahan jika ada karyawan yang lembur dalm bekerja. sedangkan untuk memberikan rasa aman karyawan dalam bekerja adalah dengan memberikan BPJS, memberikan tunjangan hari raya dan memberikan uang pensiun jika masa kerja di perusahaan tersebut sudah selesai. unit badan usaha KUD Soliamitra akan memberikan karyawan tersebut sebuah penghargaan, atas loyalitas yang di berikan karyawan

Tabel 3. Target Kinerja dan Realisasi Anggota di KUD Soliamitra-Depok Tahun 2018-2020

\begin{tabular}{|c|c|c|c|c|c|}
\hline \multirow[b]{2}{*}{ Tahun } & \multicolumn{2}{|c|}{ Jumlah Anggota } & \multirow[b]{2}{*}{$\begin{array}{c}(\mathbf{a}-\mathbf{b}) \\
\mathrm{c}\end{array}$} & \multirow{2}{*}{$\begin{array}{c}\text { Jumlah Anggota Yang Keluar } \\
\text { (Perbandingan kolom c) } \\
\text { d }\end{array}$} & \multirow{2}{*}{$\begin{array}{c}\text { Presentase Pencapaian } \\
\% \\
\left(\mathrm{~b} / \mathrm{a}^{*} 100\right) \\
\mathrm{e}\end{array}$} \\
\hline & $\begin{array}{c}\text { Target } \\
\mathbf{a}\end{array}$ & $\underset{\text { b }}{\text { Realisasi }}$ & & & \\
\hline 2018 & 7.000 & 4.752 & 2.248 & - & $67,88 \%$ \\
\hline 2019 & 7.000 & 4.278 & 2.722 & 474 & $61,11 \%$ \\
\hline 2020 & 7.000 & 4.386 & 2.614 & 108 & $62,65 \%$ \\
\hline
\end{tabular}

Sumber : Kud Soliamitra Tahun 2020

Berdasarkan informasi pada tabel di atas, menunjukan bahwa terjadi penurunan

tersebut. selama bekerja di perusahaan tersebut, dan pihak perusahaan memberikan pelatihan dan pengembangan diri pada karyawannya namun, badan usaha tersebut tidak akan memberikan bonus jika karyawan nya belum mencapai target yang atas kinerja nya.

Setiap badan usaha maupun organisasi memandang pentingnya arti perbaikan tingkat kinerja karyawan hal ini terbukti dari hasil tingkat masuknya anggota ke KUD Soliamitra dengan membandingkan jumlah target masuknya anggota dan realisasi anggota di KUD Soliamitra -Depok, dari tahun 2018-2020. 
dengan target 7.000 anggota, namun hanya terrealisasikan sebanyak 4.752 anggota setara dengan 67,88\%, pada tahun berikutnya yaitu pada tahun 2019 mengalami penurun sebanyak 4.278 anggota atau setara dengan $61,11 \%$ dan untuk tahun 2020 mengalami sedikit peningkatan yaitu dengan 4.386 atau setara dengan $62,65 \%$.

Hal ini di sebabkan karena masih banyaknya presentase disiplin karyawan yang dapat di lihat dari tingkat absensi karyawan yang tidak masuk, dan kurangnya motivasi karyawan karena masih ada nya fasilitas yang belum mereka dapatkan.

Sehingga mengakibatkan kinerja karyawan pengalami penurunan. Berdasarkan latar belakang di atas maka penulis tertarik untuk mengetahui lebih lanjut dengan melakukan penelitian yang berjudul "Pengaruh Disiplin Kerja dan Motivasi Terhadap Kinerja Karyawan KUD Soliamitra-Depok".

\section{TINJAUAN PUSTAKA}

\section{Disiplin Kerja}

Disiplin kerja adalah Disiplin kerja merupakan suatu sikap dan perilaku seseorang yang menunjukkan ketaatan, kepatuhan, kesetiaan, keteraturan dan ketertiban pada peraturan perusahaan atau organisasi dan norma-normal sosial yang berlaku. Menegakkan disiplin kerja sangat penting bagi perusahaan, adanya disiplin kerja akan menjamin terpeliharanya tata tertib dan kelancaran pelaksanaan kerja perusahaan, sehingga memperoleh hasil yang optimal. sedangkan bagi karyawan, disiplin kerja memberikan dampak suasana kerja yang menyenangkan sehingga akan menambah semangat dalam melaksanakan pekerjaannya.

Menurut Singodimedjo dalam Edy Sutrisno (2016:86), menyatakan bahwa Disiplin adalah "sikap kesediaan dan kerelaan seseorang untuk mematuhi dan menaati norma-norma peraturan yang berlaku disekitarnya".menurut Indah Puji Hartatik (2014:184) "disiplin adalah suatu alat atau sarana bagi organisasi untuk mempertahankan eksistensinya". dengan disiplin yang tinggi, para karyawan akan menaati semua peraturan yang ada, sehingga pelaksanaan pekerjaan dapat sesuai dengan rencana yang telah ditentukan". Dari beberapa pendapat di atas dapat di simpulkan bahwa disiplin kerja merupakan suatu alat untuk mengubah pola pikir dan tingkah laku seseorang agar menjadi lebih baik dan dapat meningkatkan kinerja nya.

\section{Motivasi}

Motivasi sangatlah penting untuk tingkat produktifitas bagi perusahaan, tanpa adanya motivasi dari karyawan untuk bekerja sama untuk mencapai kepentingan perusahaan, maka tujuan yang telah ditetapkan tidak akan pernah tercapai. sebaliknya, apabila terdapat motivasi yang tinggi dari karyawan, maka hal ini merupakan suatu jaminan atas keberhasilan perusahaan dalam mencapai tujuan tersebut. oleh sebab itu motivasi menjadi salah satu faktor yang paling penting sebagai penggerak dan pendorong untuk mencapai tujuan yang ingin di capai.

Menurut Notoatmodjo (2015:114), mengemukakan bahwa "motif adalah suatu perangsang keinginan dan daya penggerak kemauan bekerja seseorang karena setiap motif mempunya itu tujuan tertentu yang ingin dicapai". Menurut Maslow dalam Mangkunegara (2017:81).“motivasi merupakan kondisi atau energi yang menggerakan diri karyawan yang terarah atau tertuju untuk mencapai tujuan organisasi perusahaan".

Dari pengertian diatas dapat di simpulkan bahwa motivasi adalah dorongan yang dapat membangkitkan kemauan kerja karyawan untuk memulai melaksanakan pekerjaannya sesuai dengan tugas dan tanggung jawab yang telah di tetapkan.

3. Kinerja Karyawan 
Istilah kinerja berasal dari kata job performance (prestasi kerja) atau actual performance (prestasi yang sesungguhnya yang dapat dicapai oleh seseorang). kinerja apabila dikaitkan dengan performance sebagai kata benda (noun), maka pengertian performance atau kinerja adalah hasil kerja yang dapat dicapai oleh seseorang atau kelompok orang dalam suatu perusahaan sesuai dengan wewenang dan tanggung jawab masing-masing dalam upaya pencapaian tujuan perusahaan secara legal, tidak melanggar hukum dan tidak bertentangan dengan moral dan etika. Menurut Rivai (2014:34) "kinerja merupakan suatu fungsi dari motivasi dan kemampuan, untuk menyelesaikan tugas atau pekerjaan seseorang sepatut nya memiliki derajat kesedihan dan tingkat kemampuan tertentu". Menurut Mangkunegara (2016:79) "kinerja adalah hasil kerja secara kualitas dan kuantitas yang dicapai oleh seorang karyawan dalam melaksanakan tugasnya sesuai dengan tanggung jawab yang diberikan kepadanya".

Menurut Hasibuan

"kinerja adalah hasil kerja yang dicapai seseorang dalam melaksanakan tugastugas yang dibebankan kepadanya yang didasarkan atas kecakapan, pengalaman dan kesungguhan serta waktu". Kinerja bisa mempengaruhi berlangsung nya kegiatan suatu organisasi perusahaan, semakin baik kinerja yang ditunjukan oleh pegawai atau karyawan maka akan sangat membantu dalam perkembangan organisasi atau perusahaan. Berdasarkan pendapat di atas dapat di simpulkan bahwa kinerja karyawan adalah hasil kerja yang dicapai seseorang karyawan sesuai dengan wewenang atau tanggung jawab masing-masing pegawai selama periode dalam kurun waktu yang telah di tentukan.

\section{METODE}

Penelitian ini dilaksanakan di KUD Soliamitra - Limo Depok yang beralamat di
Jalan Limo Raya No.05, Limo,Kec Limo,Kota Depok Jawa Barat, Kode pos : 16515, Indonesia tel : 0217547925, dan untuk sosial medianya Instagram : soliamitra_1991 dan facebook : KUD Soliamitra. Populasi dalam penelitian populasinya adalah karyawan KUD Soliamitra Limo-Depok yang berjumlah 80 karyawan, teknik pengambilan sampel Jenuh, Teknik Pengumpulan Data mengunakan uji kualitas data,uji asumsi klasik,dan uji statistik.

Waktu penelitian dimulai dari bulan November 2020 - Januari 2021. Penelitian ini dilaksanakan secara berrtahap diambil dengan pra survey mulai dari pendahuluan, pengajuan proposal, pengajuan surat ijin, konsultasi, pengiriman kuisioner, dan pengolahan data penyusunan penelitian. Dalam penelitian ini peneliti mengunakan sampel jenuh, menurut sugiono (2015:68) "sample jenuh adalah teknik penentuan sampel bila semua anggota populasi digunakan sebagai sampel".

\section{HASIL DAN PEMBAHASAN}

Berdasarkan hasil penelitian yang telah diuraikan sebelumnya menunjukkan bahwa terdapat pengaruh positif dan signifikan baik secara parsial maupun simultan Disiplin kerja dan motivasi terhadap kinerja karyawan. Berikut ini dipaparkan penjelasan atas jawaban dari hipotesis penelitian.

1. Pengaruh Disiplin kerja $\left(X_{1}\right)$ Terhadap kinerja Karyawan (Y)

Dari hasil kuesioner yang telah dilakukan kepada 80 responden diperoleh hasil bahwa disiplin kerja pada KUD Soliamitra sudah baik. Penulis menyimpulkan berdasarkan hasil jawaban responden terhadap 10 pernyataan pada diperoleh rata-rata tertinggi pada pernyataan 10,1 , dan pernyataan ke 4 yaitu sebesar 4,13 dengan dengan kriteria baik, dan rata rata terendah adalah pada pernyataan 9 yaitu sebesar 3,85 dengan kriteria baik.secara keseluruhan tanggapan responden terhadap Variabel Disiplin Kerja $\left(X_{1}\right)$ adalah baik dengan jumlah 
rata jumlah rata rata 4,0 (termasuk dalam rentang skala 3,40-4,19 dengan kriteria baik).

Hasil pengujian hipotesis secara parsial (uji t) diperoleh nilai $t_{\text {hitung }}$ sebesar 4,269 dan nilai signifikasi adalah 0,000 serta nilai $t_{\text {tabel }}$ adalah 1,99125 Karena $t_{\text {hitung }}>t_{\text {tabel }}(4,269>1,99125)$ dan nilai signifikasi < 0,05 $(0,000<0,05)$ maka dapat disimpulkan bahwa Disiplin Kerja secara parsial berpengaruh signifikan terhadap kinerja karyawan.

2. Pengaruh Motivasi $\left(X_{2}\right)$ Terhadap

Kinerja Karyawan $(\mathrm{Y})$

Dari hasil kuesioner yang telah dilakukan kepada 80 responden diperoleh hasil bahwa Motivasi pada KUD Soliamitra sudah baik.

Penulis menyimpulkan berdasarkan hasil jawaban responden terhadap 10 pernyataan pada diperoleh rata-rata tertinggi pada pernyataan 1 yaitu sebesar 4,18 dengan kriteria baik dan rata-rata terendah adalah pada pernyataan 9 yaitu sebesar 3,85 dengan kriteria baik.secara keseluruhan tanggapan responden terhadap variabel motivasi $\left(X_{2}\right)$ adalah baik yaitu dari jumlah rata-rata total sebesar 4,02 (termasuk dalam rentang skala 3,40-4,19 dengan kriteria baik).

Hasil pengujian hipotesis secara parsial (uji t) diperoleh nilai $t_{\text {hitung }}$ sebesar 2,271 dan nilai signifikasi adalah 0,026 serta nilai $t_{\text {tabel }} 1,99125$ adalah Karena $t_{\text {hitung }}>t_{\text {tabel }}(2,271>1,99125)$ dan nilai signifikasi $<0,05(0,026<0,05)$ maka dapat disimpulkan bahwa Motivasi secara parsial berpengaruh signifikan terhadap kinerja karyawan.

3. Pengaruh Disiplin kerja $\left(X_{1}\right)$ dan Motivasi $\left(X_{2}\right) \quad$ Terhadap Kinerja Karyawan (Y)

Dari hasil kuesioner yang telah dilakukan kepada 80 responden diperoleh hasil bahwa kinerja karyawan pada KUD Soliamitra sudah baik. Penulis menyimpulkan berdasarkan hasil jawaban responden terhadap 10 pernyataan pada motivasi diperoleh rata-rata tertinggi pada pernyataan 1 yaitu sebesar 4,18 dengan kriteria baik dan rata-rata terendah adalah pernyataan 9 yaitu sebesar 3,85 ke dengan kriteria baik. Secara keseluruhan tanggapan responden terhadap variabel kinerja karyawan $(\mathrm{Y})$ adalah baik yaitu dari jumlah rata-rata total sebesar 4,03 (termasuk dalam rentang skala 3,40-4,19 dengan kriteria baik).

Hasil pengujian hipotesis secara simultan (uji F) diperoleh nilai $F_{\text {hitung }}$ sebesar 11,959 dan nilai signifikasi adalah 0,000 serta nilai $F_{\text {tabel }}$ pada tingkat kepercayaan 5\% sebesar 3,11. Karena $F_{\text {hitung }}>F_{\text {tabel }}(11,959>3,11)$ dan nilai signifikan < 0,05 $(0,000<0,05)$ maka dapat disimpulkan bahwa variabel disiplin kerja dan motivasi berpengaruh signifikan terhadap kinerja karyawan.

\section{KESIMPULAN DAN SARAN Kesimpulan}

Berdasarkan hasil dan analisis data yang dilakukan dalam penelitian ini mengenai pengaruh disiplin kerja dan motivasi terhadap kinerja karyawan, sebagai berikut:

1. Disiplin Kerja pada KUD Soliamitra baik, hal tersebut dibuktikan dengan hasil uji regresi linier sederhana dengan rumus $Y$ $=\mathrm{a}+\mathrm{B}_{1} \mathrm{X}_{1}$ dengan hasil $\mathrm{Y}=\mathrm{Y}=$ $22,595+0,437 X_{1}$ dan berdasarkan hasil uji $\mathrm{t}$ antara variabel disiplin kerja dan kinerja karyawan didapatkan nilai $t_{\text {hitung }}$ $>t_{\text {tabel }}(4,269>1,99125)$ menunjukan bahwa disiplin kerja berpengaruh terhadap kinerja karyawan.

2. Motivasi pada KUD Soliamitra baik, hal tersebut dibuktikan dengan hasil uji regresi linier sederhana dengan rumus $\mathrm{Y}=\mathrm{a}+\mathrm{B}_{2} \mathrm{X}_{2}$ dengan hasil $\mathrm{Y}=29,735+0,262$ $\mathrm{X}_{2}$ dan berdasarkan hasil uji $\mathrm{t}$ antara variabel motivasi dan kinerja karyawan didapatkan $t_{\text {hitung }}>t_{\text {tabel }}(2,271>1,99125)$ menunjukan bahwa Motivasi berpengaruh terhadap kinerja karyawan.

3. Terdapat berpengaruh bersama-sama antara disiplin kerja dan motivasi terhadap kinerja karyawan pada KUD Soliamitra dengan uji regresi linier berganda dengan rumus $\mathrm{Y}=\mathrm{b}_{1} \mathrm{X}_{1}+\mathrm{b}_{2} \mathrm{X}_{2}$ 
dengan hasil $\mathrm{Y}=12,807+0,431\left(\mathrm{X}_{1}\right)+$ $0,249\left(X_{2}\right)$ dan hasil uji $F$ dimana nilai $F_{\text {hitung }}>F_{\text {tabel }}(11,959>3,11)$ dengan nilai koefisien determinasi $\left(\mathrm{r}^{2}\right)$ yang diperoleh sebesar 0,217 atau $21,7 \%$ sedangkan sisanya sebesar 0,783 atau $78,3 \% \%$ disebabkan oleh faktor lain yang tidak diteliti dalam penelitian ini.

\section{Saran}

Berdasarkan kesimpulan hasil penelitian mengenai pengaruh disiplin kerja dan motivasi terhadap kinerja karyawan di KUD Soliamitra Limo-Depok. maka peneliti akan mengemukakan beberapa saran yang dapat dijadikan solusi dari pembahasan. adapun saran-saran yang ingin peneliti sampaikan adalah sebagai berikut :

1. Disiplin kerja pernyataan yang paling lemah adalah nomor 9 yaitu karyawan menggunakan peralatan kerja dengan baik sesuai standart yang sudah di tetapkan oleh KUD Soliamitra. dimana hanya mencapai score sebesar 3,85. untuk lebih baik sebaiknya pemimpin harus melakukan pelatihan kepada seluruh karyawannya dalam hal pelatihan dalam bidang teknologi yang di gunakan dan di tetapkan oleh badan usaha tersebut, dan pastikan seluruh karyawan bisa dan mampu menggunakan peralatan kerja lebih baik dan sesuai standar badan usaha tersebut untuk mendapatkan kualitas kerja yang lebih baik dan maksimal.

2. Variabel Pelatihan, pernyataan yang paling lemah adalah para pelatih menguasai materi yang diberikan saat pelatihan, dimana hanya mencapai score 3.70. Disarankan untuk perusahaan memiliki pelatih yang menguasai materi dan pelatih telah tersertifikasi. Dan indikator-indikator lainnya pada variable pelatihan kerja harus ditingkatkan lagi serta dilakukan secara berkelanjutan untuk meningkatkan keterampilan para karyawan.

3. Variabel Disiplin, pernyataan yang paling lemah adalah indikator keteladanan pimpinan yaitu pimpinan selalu memberikan suri tauladan yang pantas dicontoh oleh bawahannnya, dimana hanya mencapai score sebesar 3.76. Mengingat disiplin kerja merupakan salah satu faktor penting dalam meningkatkan kinerja yang optimal maka pimpinan disarankan untuk memberikan contoh disiplin yang baik pada bawahannya karena untuk menghindari kecemburuan sosial di lingkungan kerja.

4. Variabel Kinerja Karyawan, pernyataan yang paling lemah adalah dalam bekerja saya bertanggung jawab akan pekerjaan saya, dimana hanya mencapai score sebesar 3.76.

Perusahaan perlu melakukan penilaian kinerja berdasarkan pertimbangan bahwa perlu adanya suatu evaluasi kinerja yang objektif. Selain itu, dengan adanya penilaian kinerja dapat memberikan kompensasi yang sesuai dengan prestasi yang telah dicapai. Semua diharapkan dapat membentuk motivasi kepada masingmasing karyawan agar dapat bekerja secara efisien dan efektif.

5. Untuk penelitian berikutnya disarankan untuk memperhatikan variable lain yang berpengaruh terhadap kinerja karyawan diluar pelatihan dan disiplin kerja selain itu juga disarankan untuk penelitian selanjutnya dapat diperdalam dan dilengkapi dengan kuesioner terbuka mengingat masih banyak keterbatasan dalam penelitian ini.

\section{DAFTAR PUSTAKA}

Agustin, F. (2021). Pengaruh Gaya Kepemimpinan Terhadap Kinerja Karyawan Pada PT. Gama Panca Makmur Di Tangerang. JENIUS (Jurnal Ilmiah Manajemen Sumber Daya Manusia), 4(2), 128-136.

Algifari.(2011). Analisis Regresi, Teori, Kasus $\mathcal{E}$ Solusi. Yogyakarta: BFFE UGM. Anwar,S.(2012).Metode Penelitian Bisnis.Jakarta:Salemba Empat.

Arikunto,S.(2013).Prosedur Penelitian Suatu Pendekatan Praktek. Jakarta: Rineka Cipta. 
Athoillah, A.(2013).Dasar-dasar Manajemen. Bandung: CV Pustaka Setia.

Bangun,W.(2012).Manajemen Sumber daya Manusia. Jakarta : Erlangga.

Ghozali, I.(2016). Aplikasi Analisis Multivariete Dengan Program IBM SPSS 23 (Edisi 8). Cetakan ke VIII. Semarang : Badan Penerbit Universitas Diponegoro.

Hartatik,\&Indah,P.(2014). Buku Praktis Mengembangkan SDM.Yogyakarta: Laksana.

Hasibuan, S.P M.(2012).Manajemen Sumber Daya manusia.Jakarta :PT. Bumi Aksara.

Hidayat, D. (2020). Pengaruh Kepemimpinan Dan Motivasi Terhadap Kinerja Karyawan Pada PT. Agung Abadi Di Jakarta. JENIUS (Jurnal Ilmiah Manajemen Sumber Daya Manusia), 4(1), 22-32.

Kadarsiman.(2012).Manajemen Kompensasi.Jakarta: Rajawali Press.

Kristianti, L. S., Affandi, A., Nurjaya, N., Sunarsi, D., \& Rozi, A. (2021). Pengaruh Motivasi Dan Disiplin Kerja Terhadap Kinerja Pegawai Pada Dinas Pariwisata Purwakarta. Jurnal Ilmiah PERKUSI, 1(1), 101-109.

Mangkunegara,A.(2012).Manajemen Sumber Daya Manusia.Bandung: PT. Remaja Rosdakarya.

Nurjaya, N., et al (2021). The Effect of Product Promotion and Innovation Activities on Marketing Performance in Middle Small Micro Enterprises in Cianjur. Budapest International Research and Critics Institute (BIRCIJournal): Humanities and Social Sciences, $4(1), 528-540$.

(2021). Pengaruh Kompetensi Sumber Daya Manusia Dan Kemampuan Pemanfaatan Teknologi Terhadap Kinerja Aparatur Desa Pada Kantor Kepala Desa Di Kabupaten Gunungkidul, Yogyakarta. JENIUS
(Jurnal Ilmiah Manajemen Sumber Daya Manusia), 4(3), 332-346.

Paramarta, V., Dewi, R. R. V. K., Rahmanita, F., Hidayati, S., \& Sunarsi, D. (2021). Halal Tourism in Indonesia: Regional Regulation and Indonesian Ulama Council Perspective. International Journal of Criminology and Sociology, 10, 497-505.

Prasada, D., Sunarsi, D., \& Teriyan, A. (2020). Pengaruh Etos Kerja Dan Kompensasi Terhadap Komitmen Organisasi Pada DHL Logistic Di Jakarta. JENIUS (Jurnal Ilmiah Manajemen Sumber Daya Manusia), $4(1), 51-60$.

Rivai, V. (2014). Msdm Perusahaan dari Teori Ke Praktik Edisi Ketiga Cetakan Keenam. Jakarta: Raja Grafindo Persada.

Robbins,S.,\&Coulter,M.(2012).Manajemen.Ja karta: PT.Indeks Kelompok Gramedia.

Safroni, L.(2013).Manajemen dan Reformasi Pelayanan Publik dalam Konteks Birokrasi Indonesia. Surabaya : Aditya Media Publishing.

Salam,B.(2014).Manajemen Pemerintahan. Jakarta : PT. Djambatan.

Santoso,S.(2012).Panduan Lengkap SPSS Versi 20. Jakarta: PT Elex Media Komputindo.

Sudjana, N. (2013). Penilaian Hasil Proses Belajar Mengajar. Bandung: PT Remaja Rosdakarya.

Sugiyono.(2012).Statistika Untuk Penelitian. Bandung: ALFABETA.

Suharsimi,A.(2013). Manajemen Penelitian. Jakarta : PT Rineka Cipta.

Sunarsi, D. (2018). Pengaruh Gaya Kepemimpinan dan Disiplin Kerja Terhadap Kinerja Karyawan Pada CV. Usaha Mandiri Jakarta. JENIUS (Jurnal Ilmiah Manajemen Sumber Daya Manusia), 1(2).

Sutrisno,E.(2014).Manajemen Sumber Daya Manusia Cetakan ke Enam.Jakarta:Pranada Media Group. 